\title{
Deposition of lodine-131 on Plant Leaves (1)
}

\author{
Yoichiro Oнмомо and Masamichi SAIKI \\ Tokai Laboratory, Tokai Branch, National Institute \\ of Radiological Sciences, Tokai, Japan \\ Received September 24, 1970
}

\begin{abstract}
This experiment was carried out in order to know the deposition and the distribution of $\mathrm{CH}_{3}{ }^{131} \mathrm{I},{ }^{131} \mathrm{I}_{2}$ and $\mathrm{Na}^{131} \mathrm{I}$ on plant leaves such as spinach, Chinese cabbage, Komatsuna and camellia quantitatively and autoradiographically. $\mathrm{CH}_{3}{ }^{131} \mathrm{I}$ deposited on Chinese cabbage, spinach and camellia leaves on the similar level. On the contrary, ${ }^{131} \mathrm{I}_{2}$ deposited strongly on spinach and Chinese cabbage leaves and slightly deposited on camellia leaves. It was suggested that ${ }^{131} \mathrm{I}_{2}$ deposited more strongly on leafy vegetables than $\mathrm{CH}_{3}{ }^{131} \mathrm{I}$. Both $\mathrm{CH}_{3}{ }^{131} \mathrm{I}$ and ${ }^{131} \mathrm{I}_{2}$ were concentrated in the vein of the leaves. No radioactivity was detected on the leaves which were steeped in the $\mathrm{Na}^{131} \mathrm{I}$ solution.

Effective removal of iodine-131 from the contaminated leaves reas not clearly recognized by washing them with detergent, $\mathrm{CCl}_{4}$, ether, $0.5 \mathrm{~N} \mathrm{HCl}$ and $0.5 \mathrm{~N} \mathrm{NaOH}$.
\end{abstract}

\section{Introduction}

Iodine-131, which is one of the most popular fission products, is an important radionuclide to human body, because it is concentrated in thyroid gland. If it was released in the air, it could be taken up through inhalation, drinking water and food such as milk and vegetables. Studies of chemical form, distribution and concentration of iodine-131 in different environmental substances or organisms are required for the estimation of radiation hazard due to radioactive iodine, which is supplied from nuclear explosion test or released in the air from nuclear power plant especially in an emergency. In a series of nuclear explosion tests sometimes significant amount of radioactive iodine was detected in cow's milk ${ }^{1)}$. And the maximum radiation dose to thyroid gland of infant was estimated ${ }^{2}$. Distribution of iodine-131 in milk and the deposition of ${ }^{131} I_{2}$ on plant leaves have been studied. However, information on the influence of the chemical form of iodine upon the deposition of different kinds of plant leaves is quite limited. This experiment was carried out in order to know the deposition and the distribution of organic and inorganic iodine131 on plant leaves such as spinach, Chinese cabbage, Komatsuna, camellia and also filter paper and carbon filter paper. Removal of these iodine compounds from leaves was also examined by washing them with several kinds of chemicals.

\section{Procedure}

2.1 Apparatus

Outline of the experimental apparatus is shown in Fig. 1. Evaporated gases were introduced to exposure vessel through glass wool, which is connected to traps, by suction at the flow rate of $1,000 \mathrm{~m} l /$ hour.

\subsection{Plant leaves}

Spinach (Spinacia oleracea L.), Chinese cabbage ( $B$. rapa var. amplexicaulis subvar. Pe-tsai), Camellia (Camellia japonica L.) and Komatsuna (B. rapa var. Komatsuna) leaves were used. Especially in case of a Chinese cabbage, a small whole was used.

\section{$2 \cdot 3$ Exposure}

2.3.1 For the primary qualitative experiment

Seven $\mu \mathrm{Ci}$ of $\mathrm{CH}_{3}{ }^{131} \mathrm{I}$ containing $125 \mathrm{mg}$ of 


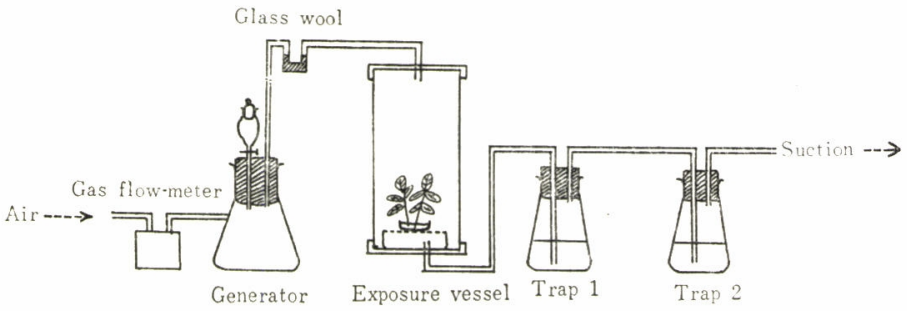

Fig. 1 Outline of the experimental apparatus.

stable $\mathrm{CH}_{3} \mathrm{I}$ was evaporated by warming over $40^{\circ} \mathrm{C}$ and contacted with spinach leaves, camellia leaves, filter paper and carbon filter paper (carbon powder attached filter paper) in exposure vessel for 60 minutes. Three point of five $\mu \mathrm{Ci}$ of ${ }^{131} \mathrm{I}_{2}$ containing $20 \mathrm{mg}$ of stable $\mathrm{I}_{2}$ was released by adding dropwise 1 or $2 \mathrm{ml}$ of $30 \% \mathrm{H}_{2} \mathrm{O}_{2}$ to the $\mathrm{Na}^{131} \mathrm{I}$ solution which contained $0.5 \mathrm{~g}$ of $\mathrm{Fe}_{2}\left(\mathrm{SO}_{4}\right)_{3}$ and $0.5 \mathrm{ml}$ of concentrated $\mathrm{H}_{2} \mathrm{SO}_{4}$ and contacted with the samples mentioned above.

\section{$2 \cdot 3 \cdot 2$ For the quantitative experiment}

Twenty $\mu \mathrm{Ci}$ of $\mathrm{CH}_{3}{ }^{131} \mathrm{I}$ containing 50 and $225 \mathrm{mg}$ of stable $\mathrm{CH}_{3} \mathrm{I}$ was evaporated and exposed to spinach, Chinese cabbage, filter paper and carbon filter paper for 60 minutes. Twenty $\mu \mathrm{Ci}$ of ${ }^{131} \mathrm{I}_{2}$ containing $100 \mathrm{mg}$ of stable $\mathrm{I}_{2}$ and $52 \mu \mathrm{Ci}$ of ${ }^{131} \mathbf{I}_{2}$ containing 10 and $100 \mathrm{mg}$ of stable $\mathbf{I}_{2}$ were released and contacted with the samples mentioned above for 60 minutes. After that the leaves were washed with running water and patted softly with paper towel for removing water.

\subsection{Measurement of radioactivity and autoradiography}

The radioactivity was measured by means of GM counter having $6 \mathrm{~cm}^{2}$ of window area after covering the contaminated leaves with very thin membrane. The results were shown as ${ }^{131} \mathrm{I}\left(\mathrm{cpm} / 6 \mathrm{~cm}^{2}\right)$ and the distribution was checked autoradiographically. Fuji X-ray film $(27.0 \mathrm{~cm} \times 35.6 \mathrm{~cm})$, which was made by $\mathrm{Fuji}$ Film Co., Ltd., was used for the autoradiography.

\subsection{Removal}

Removal of $\mathrm{CH}_{3}{ }^{131} \mathrm{I}$ and ${ }^{131} \mathrm{I}_{2}$ was examined by washing the contaminated leaves with detergent, $\mathrm{CCl}_{4}$, ether, $0.5 \mathrm{~N} \mathrm{HCl}$ and $0.5 \mathrm{~N} \mathrm{NaOH}$.

Experiment was carried out in a darkened hood in order to avoid the decomposition of the evaporated iodine compounds by light.

\section{Results and Discussions}

It was rather difficult to identify the chemical form of the evaporated $I_{2}$ when it was released by the oxidation of the carrier free $\mathrm{Na}^{131} \mathrm{I}$ and therefore in this experiment adequate amount of stable sodium iodide carrier was added to the radioactive solution in order to sustain the existence of $I_{2}$ from its proper violet color and also to know the effect of the carrier. It was conjectured that thus evaporated $I_{2}$ vapor probably contained the other chemical form of inorganic iodine such as iodine oxide or iodine peroxide. For convenience, however, iodine vapor generated by the oxidation of sodium iodide was expressed. as $I_{2}$ vapor in this paper.

\subsection{Qualitative experiment}

Deposition of $\mathrm{CH}_{3}{ }^{131} \mathrm{I}$ and ${ }^{131} \mathrm{I}_{2}$ on spinach, camellia, filter paper and carbon filter paper was shown in Fig. 2 and Fig. 3 respectively.

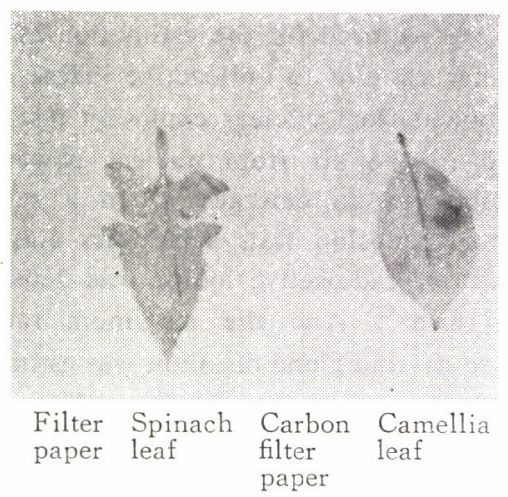

Exposure time to film: 160 hours Development time: 10 minutes

Fig. 2 Deposition of $\mathrm{CH}_{3}{ }^{131} \mathrm{I}$ on spinach leaf, camellia leaf, filter paper: and carbon filter paper. 


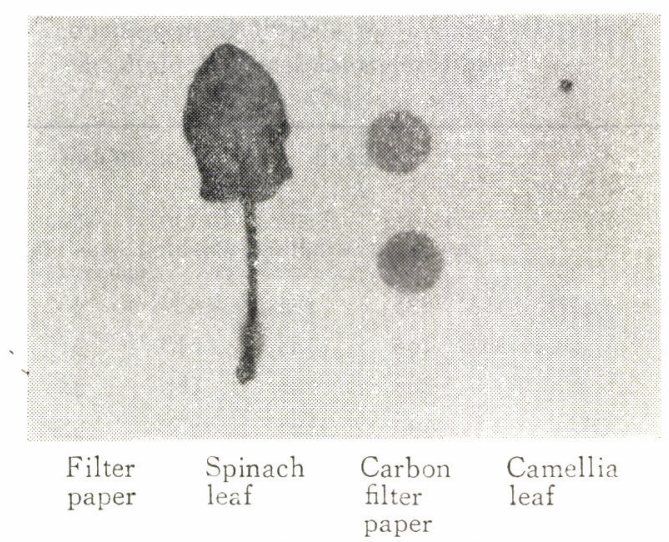

Exposure time to film: 20 hours

Development time: 3 minutes

Fig. 3 Deposition of ${ }^{131} \mathrm{I}_{2}$ on spinach leaf, camellia leaf, filter paper and carbon filter paper.

$\mathrm{CH}_{3}{ }^{131} \mathrm{I}$ was deposited on spinach and camellia leaves on the similar level, but detectable amount of radioactivity was not observed on filter paper and carbon filter paper. On the contrary, ${ }^{131} \mathrm{I}_{2}$ was strongly attached on spinach leaves and carbon filter paper, and also slight deposition was found on camellia leaves and filter paper. This suggested that it would be possible to distinguish evaporated $I_{2}$ from $\mathrm{CH}_{3} \mathrm{I}$ indirectly by measuring the radioactivity deposited on the carbon filter paper. In spite of the slight deposition of ${ }^{131} \boldsymbol{I}_{2}$ on the surface of the camellia leaves, remarkable sorption was observed at the end of the stalk. When it was sealed by wax, as shown in Fig. 4, no deposition was observed. This suggested that

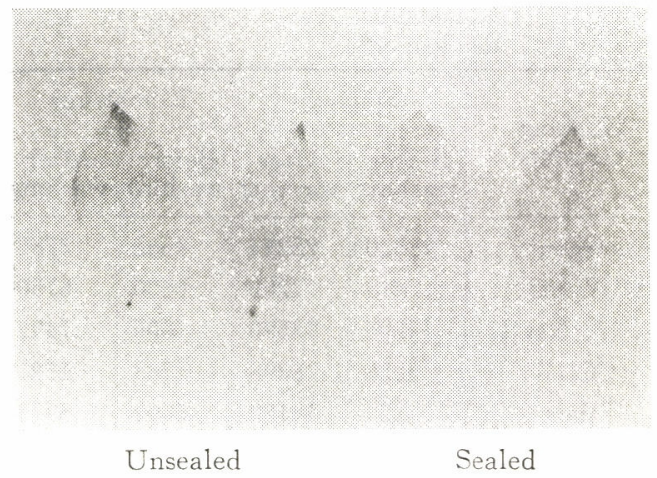

Fig. 4 Deposition of ${ }^{131} \mathrm{I}_{2}$ on the camellia leaves, the ends of the stalks of which were unsealed and sealed by wax. the wax-like material on the surface of the camellia leaves might inhibit the sorption of ${ }^{131} \mathrm{I}_{2}$. It was recognized that both $\mathrm{CH}_{3}{ }^{131} \mathbf{I}$ and ${ }^{131} \mathrm{I}_{2}$ were concentrated in the vein of the leaves.

\subsection{Quantitative experiment}

Concentration of $\mathrm{CH}_{3}{ }^{131} \mathrm{I}$ and ${ }^{131} \mathrm{I}_{2}$ on one or three fixed areas on spinach and Chinese cabbage leaves were measured, as shown in Table 1 and 2, in order to know the level of the deposition of both vapors quantitatively.

Table 1 Average concentration of $\mathrm{CH}_{3}{ }^{131} \mathrm{I}$ on a Chinese cabbage* and spinach leaves $\left(\mathrm{cpm} / 6 \mathrm{~cm}^{2}\right.$ of the leaves)

\begin{tabular}{c|c|c|c|c}
\hline $\begin{array}{c}\text { Amount of } \\
\mathrm{CH}_{3}{ }^{131} \mathrm{I} \\
\text { evaporated }\end{array}$ & \multicolumn{3}{|c|}{ Chinese cabbage* } & Spinach \\
\cline { 2 - 5 } $\begin{array}{c}\text { (Amount of } \\
\mathrm{CH}_{3} \mathrm{I} \text { carrier) }\end{array}$ & $\begin{array}{c}\text { Upper } \\
\text { part }\end{array}$ & $\begin{array}{c}\text { Central } \\
\text { part }\end{array}$ & $\begin{array}{c}\text { Lower } \\
\text { part }\end{array}$ & $\begin{array}{c}\text { Central } \\
\text { part }\end{array}$ \\
\hline $\begin{array}{c}20 \mu \mathrm{Ci} \\
(45 \mathrm{mg})\end{array}$ & 207 & 68 & 59 & 431 \\
$\begin{array}{c}20 \mu \mathrm{Ci} \\
(200 \mathrm{mg})\end{array}$ & 240 & 202 & 53 & 413 \\
\hline
\end{tabular}

* Outside leaf

Table 2 Average concentration of ${ }^{131} \mathrm{I}_{2}$ on a Chinese cabbage* and spinach leaves $\left(\mathrm{cpm} / 6 \mathrm{~cm}^{2}\right.$ of the leaves)

\begin{tabular}{l|r|r|r|r}
\hline $\begin{array}{c}\text { Amount of } \\
{ }_{131} \mathrm{I}_{2} \\
\text { evaporated }\end{array}$ & \multicolumn{3}{|c|}{ Chinese cabbage* } & Spinach \\
\cline { 2 - 5 } $\begin{array}{c}\text { (Amount of } \\
\mathrm{I}_{2} \text { carrier) }\end{array}$ & $\begin{array}{c}\text { Upper } \\
\text { part }\end{array}$ & $\begin{array}{c}\text { Central } \\
\text { part }\end{array}$ & $\begin{array}{c}\text { Lower } \\
\text { part }\end{array}$ & $\begin{array}{c}\text { Central } \\
\text { part }\end{array}$ \\
\hline $\begin{array}{c}20 \mu \mathrm{Ci} \\
(100 \mathrm{mg})\end{array}$ & 2892 & 831 & 904 & 1939 \\
$52 \mu \mathrm{Ci}$ \\
$\begin{array}{c}(100 \mathrm{mg}) \\
52 \mu \mathrm{Ci} \\
(10 \mathrm{mg})\end{array}$ & 10387 & 4928 & 4883 & 19712 \\
\hline
\end{tabular}

* Outside leaf

It was recognized that ${ }^{131} \mathbf{I}_{2}$ deposited more than ten times as much as $\mathrm{CH}_{3}{ }^{131} \mathbf{I}$ for the same level of the evaporation $(20 \mu \mathrm{Ci})$. That was also clearly recognized from darker autoradiograph of the ${ }^{131} \mathrm{I}_{2}$-deposited leaves shown in Fig. 6 though the film was shorter exposed to the contaminated leaves and also to a developing solution than that of the autoradiograph of the $\mathrm{CH}_{3}{ }^{131} \mathrm{I}$-deposited leaves shown in Fig. 5. The difference of the amount of the carrier had no effect on the deposition 


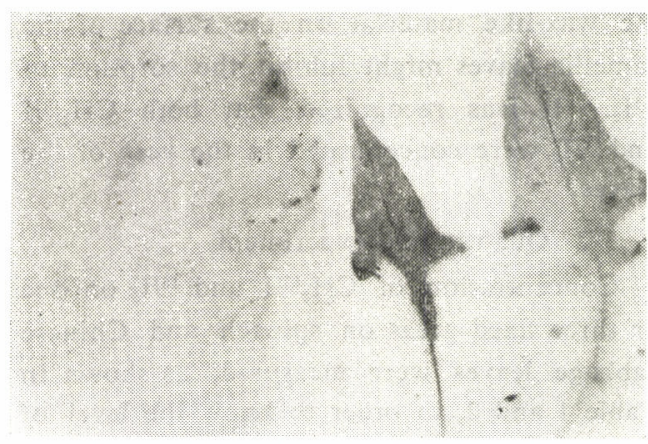

A Chinese cabbage Spinach leaves leaf

Exposure time to film: 160 hours

Development time: 10 minutes
Table 3 Removal of $\mathrm{CH}_{3}{ }^{131} \mathrm{I}$ from spinach and Komatsuna leaves $\left(\mathrm{cpm} / 6 \mathrm{~cm}^{2}\right.$ of the leaves*)

\begin{tabular}{|c|c|c|c|c|}
\hline \multirow{2}{*}{$\begin{array}{l}\text { Washing } \\
\text { reagents }\end{array}$} & \multicolumn{2}{|c|}{ Spinach } & \multicolumn{2}{|c|}{ Komatsuna } \\
\hline & $\begin{array}{c}\text { Before } \\
\text { washing }\end{array}$ & $\begin{array}{c}\text { After } \\
\text { washing }\end{array}$ & $\begin{array}{c}\text { Before } \\
\text { washing }\end{array}$ & $\begin{array}{c}\text { After } \\
\text { washing }\end{array}$ \\
\hline Detergent & 225 & 181 & 459 & 432 \\
\hline $0.5 N \mathrm{HCl}$ & 164 & 155 & 513 & 476 \\
\hline $0.5 \mathrm{~N} \mathrm{NaOH}$ & 308 & 278 & 596 & 515 \\
\hline $\mathrm{CCl}_{4}$ & 199 & 187 & 256 & 254 \\
\hline Ether & 305 & 287 & 406 & 387 \\
\hline
\end{tabular}

* Activity was measured on the same place before and after washing.

Fig. 5 Deposition of $\mathrm{CH}_{3}{ }^{131} \mathrm{I}$ on a Chinese cabbage and spinach leaves.

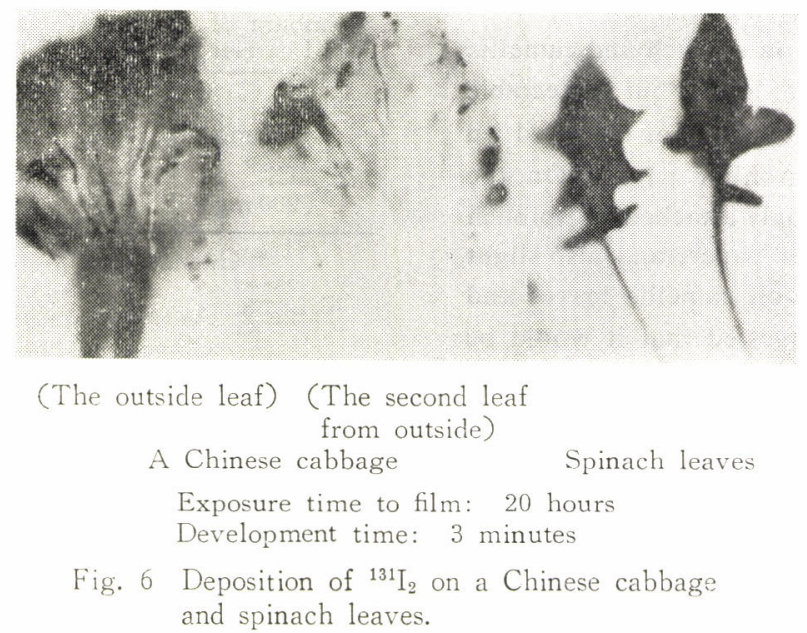

level for both $\mathrm{CH}_{3}{ }^{131} \mathrm{I}$ and ${ }^{131} \mathbf{I}_{2}$, presumably caused by the physical disorder of the leaves damaged by the corrosive iodine vapor coming from comparatively much quantity of the carrier used for this experiment.

No activity was recognized from the leaves which were steeped in $\mathrm{Na}^{131}$ I solution.

Removal of $\mathrm{CH}_{3}{ }^{131} \mathrm{I}$ and ${ }^{131} \mathrm{I}_{2}$ from the contaminated leaves was examined by washing them with detergent, $\mathrm{CCl}_{4}$, ether, $0.5 \mathrm{~N} \mathrm{HCl}$ and $0.5 \mathrm{~N} \mathrm{NaOH}$. As shown in Table 3 and 4 , effective removal was not clearly recognized. Ohno, et al. ${ }^{6)}$ showed that radioactive iodine on the leaves contaminated by radioactive fallout arised from Chinese Nuclear Explosion Test was effectively removed by washing with
Table 4 Removal of ${ }^{131} \mathrm{I}_{2}$ from spinach and Komatsuna leaves $\left(\mathrm{cpm} / 6 \mathrm{~cm}^{2}\right.$ of the leaves*)

\begin{tabular}{l|r|r|r|r}
\hline \multirow{2}{*}{$\begin{array}{l}\text { Washing } \\
\text { reagents }\end{array}$} & \multicolumn{2}{|c|}{ Spinach } & \multicolumn{2}{c}{ Komatsuna } \\
\cline { 2 - 4 } \cline { 5 - 5 } & $\begin{array}{c}\text { Before } \\
\text { washing }\end{array}$ & $\begin{array}{c}\text { After } \\
\text { washing }\end{array}$ & $\begin{array}{c}\text { Before } \\
\text { washing }\end{array}$ & $\begin{array}{c}\text { After } \\
\text { washing }\end{array}$ \\
\hline Detergent & 28330 & 25224 & 4562 & 3786 \\
$0.5 \mathrm{~N} \mathrm{HCl}$ & 7470 & 7262 & 6836 & 5750 \\
$0.5 \mathrm{~N} \mathrm{NaOH}$ & 14206 & 14590 & 7606 & 7492 \\
$\mathrm{CCl}_{4}$ & 5858 & 5398 & 1788 & 1526 \\
Ether & 14224 & 14182 & 5992 & 5978 \\
\hline
\end{tabular}

* Activity was measured on the same place before and after washing.

water. It was conjectured that radioactive iodine on the leaves contaminated by fallout 
might exist as particles or be attached to the dust and soil on the leaves, and therefore it might be easily washed away with water, while in our experiment the evapolated iodine might combine strongly with leaves which were previously cleaned out by running water and it would be difficult to remove it by washing.

\section{Conclusion}

$\mathrm{CH}_{3}{ }^{131} \mathrm{I}$ and ${ }^{131} \mathrm{I}_{2}$ evaporated from generator were exposed to Chinese cabbage, spinach, Komatsuna and camellia leaves, and also filter paper and carbon filter paper. And the deposition and the distribution were investigated quantitatively and autoradiographically.

$\mathrm{CH}_{3}{ }^{131} \mathrm{I}$ deposited on Chinese cabbage, spinach and camellia leaves on the same level, but significant radioactivity was not observed on filter paper and carbon filter paper. On the contrary, ${ }^{131} \mathbf{I}_{2}$ deposited strongly on spinach, Chinese cabbage and carbon filter paper and slightly deposited on camellia and filter paper. It was conjectured that wax-like material of the surface of camellia leaves might inhibit the sorption of ${ }^{131} \mathrm{I}_{2}$. It was suggested that ${ }^{131} \mathrm{I}_{2}$ deposited more strongly on leafy vegetables than $\mathrm{CH}_{3}{ }^{131} \mathrm{I}$. Both $\mathrm{CH}_{3}{ }^{131} \mathrm{I}$ and ${ }^{131} \mathrm{I}_{2}$ were concentrated in the vein of the leaves. No radioactivity was detected from the leaves which were steeped in the $\mathrm{Na}^{131}$ I solution.

Effective removal of iodine-131 from the contaminated leaves was not clearly recognized by washing them with detergent, $\mathrm{CCl}_{4}$, ether, $0.5 \mathrm{~N} \mathrm{HCl}$ and $0.5 N \mathrm{NaOH}$.

\section{Acknowledgement}

The authors wish to express their sincere thanks to Miss Haruko Yamaguchi for her kind help for the experiment.

\section{References}

1) Radioactivity Survey Data in Japan, 16, 47 (1967)

2) M. Saiki, G. Tanaka and Y. Ohmomo: Estimation of Radiation Doses in Infant, due to a Series of Chinese Nuclear Detonation Tests, National Institute of Radiological Sciences, Annual Report, 10. 65 (1966)

3) Y. Ohmomo and M. Saiki: Distribution and Chemical Form of ${ }^{131} \mathbf{I}$ in Cow's Milk, National Institute of Radiological Sciences, Annual Report, 9, 101 (1965)

4) P.J. Barry and A.C. Chamberlain: Deposition of Iodine onto Plant Leaves from Air, Health Physics, 9, (12) 1149 (1963)

5) C. A. Hawley, Jr., C.W. Sill and G. L. Voelz: Controlled Environmental Radioiodine Test at the National Reactor Testing Station, IDO-12035 (1964)

6) S. Ohno, G. Tanaka and M. Saiki: Removal of Radioactive Iodine from Vegetables Contaminated by Fallout, Personal Information (1966)

\title{
要 旨
}

\section{放射性ヨウ素の葉面付着に関する研究 (1)}

\author{
大桃洋一郎, 佐伯誠道 \\ 放射線医学総合研究所, 東海研究室
}

\begin{abstract}
放射性ヨウ素が，植物の葉面にどのように付着するかを知るために, $\mathrm{CH}_{3}{ }^{131} \mathrm{I},{ }^{131} \mathrm{I}_{2}$ お よび $\mathrm{Na}^{131} \mathrm{I}$ による付着状態を, ホウレン草, キャベッ, 小松菜拉び椿の葉について観察し, さらに水洗, 中

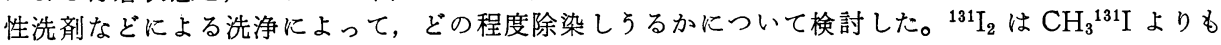
より多く付着するが, $\mathrm{Na}^{131} \mathrm{I}$ 水溶液の葉面からのとり込みは認められなかった。この事実は, ヨウ 素のとり込みが気孔を通して行なわれ単なる物理的付着だけではないことを示唆しているるのと考 えられる。葉面からとり込まれたヨウ素は葉脈に濃縮されることが明らかにされた。水, 中性洗剤, 酸, アルカリ，エーテルによる除染効果は，顕著には認められなかった。
\end{abstract}

